\title{
Effect of Different Packaging Materials and Storage Environments on Seed Quality of Sesame (Sesamum Indicum L.)
}

\author{
Hnin Thida Nyo (Corresponding author) \\ Department of Agriculture, Ministry of Agriculture, Livestock and Irrigation, Myanmar \\ Tel: 95-9-444029464Ｅ-mail: hninnyo@gmail.com \\ Nyein Nyein Htwe \\ Professor, Department of Agricultural Extension, Yezin Agricultural University, \\ Myanmar
}

Kyaw Kyaw Win

Pro-rector, Yezin Agricultural University, Myanmar

Received: June 27, 2019 Accepted: August 21, 2019

doi:10.5296/jbls.v11i1.15405 URL: https://doi.org/10.5296/jbls.v11i1.15405

\begin{abstract}
The speed of the deterioration of oil-seeds depends on conditions of the storage environment and understanding dormancy release time is important to increase the amount and uniformity in germination. Therefore, the present study was conducted to evaluate the effect of different packaging materials and storage environments on viability and dormancy of sesame. The black sesame seed was stored in three packaging materials (woven polypropylene bag, IRRI super bag, metal bin) under two environment conditions (ambient and cold storage) for eight-month (initial storage, 2-month, 4-month, 6-month and 8-month). The effect of storage environments, packaging materials and storage durations on germination percentage, germination index, seedling vigor index I and II were significant. The moisture content decreased in the early parts of storage periods and then increased in later. The moisture content of seeds in the packaging materials increased in long storage due to the effect of seed respiration and heat accumulation in a package. Higher viability was observed in ambient storage, and in a woven polypropylene bag. Because the dormancy release was slow in lowtemperature condition and the carbon dioxide concentration in the airtight package inhibited the dormancy break. It also increased during storage and the earliest fully dormancy break has occurred in six-month of woven polypropylene bag storage under ambient condition.
\end{abstract}


Therefore, the germination and dormancy release of sesame were influenced by storage environments packaging materials and storage durations.

Keywords: black sesame, packaging materials, storage duration, germination, dormancy

\section{Introduction}

Seed deterioration starts immediately after a crop has attained the physiological maturity stage. The process of seed deterioration could be associated with some physiological changes, such as a progressive decrease in germinability, increase mean time of germination and increase in the number of abnormal seedlings and lower tolerance to adverse storage conditions (Hendry, 1993).

Sesame deterioration is even faster immediately after harvest from the field due to its high oil content and fast cellular respiration occurring in the seed (Oyekale et al., 2012). The speed of the deterioration of oil-seeds depends on conditions of the storage environment and on particularities of the species, which include the seed chemical composition. Their oil content readily oxidizes, which deteriorate the seed health in storage. The seed storage environment greatly influences the period of seed survival. The type of packaging during storage supposes relevant importance on seed and the packaging indeed helps on lessening the speed of deterioration by maintaining the initial moisture content of seeds stored, and by diminishing, or not, their respiration rate (Brooker et al., 1992).

Seed dormancy is a temporary condition whereby mature and viable seeds fail to germinate up to a specific time under favorable conditions (Tung \& Serrano, 2011). Dormancy helps to prevent losses due to germination during harvesting and storage in case of unfavorable weather (Wu et al., 2016). However, having a dormant lot by the time sunflower seeds are sold for sowing is a significant problem that most seed companies face frequently (Roberto, 2004). Maintaining the viability of seeds by storing them under controlled environmental conditions and understanding dormancy release time are important to increase the amount and uniformity in germination. Thus, the present study was conducted to evaluate the effect of different packaging materials and storage environments on viability and dormancy of sesame.

\section{Materials and Methods}

\subsection{Experimental Site}

This experiment was carried out at the laboratory of the Department of Agronomy, Yezin Agricultural University from August 2016 to March 2017. The tested sesame variety was black sesame (Samonnet) which was collected from Seed Production Farm, Department of Agriculture, Pwintphyu Township in Magway Region.

\subsection{Experimental Design}

A randomized complete block $(\mathrm{RCB})$ design was laid out in $2 \times 3 \times 5$ factorial experiments with three replications. The treatments were: Factor A: Storage environments (E1 - Ambient storage, E2 - Cold storage $-10{ }^{\circ} \mathrm{C}$ and $\sim 50 \% \mathrm{RH}$ ); Factor B: Packaging materials (P1 - 
Woven polypropylene bag, P2 - IRRI super bag, P3 - Metal bin); Factor C: Storage durations (D0 - Initial storage, D1 - Two-month, D2 - Four-month, D3 - Six-month, D4 Eight-month).

\subsection{Experimental Procedure}

The 500 gm of sesame seed were thoroughly cleaned and placed in woven polypropylene bags, IRRI super bags and metal bins. The IRRI super bags were tightly tied and placed in woven polypropylene bags, and metal bins were sealed with plastic tape. Then the containers were placed in the laboratory room for ambient storage and in a refrigerator at temperature 10 ${ }^{\circ} \mathrm{C}$ and relatively humidity of $50 \pm 5 \%$ for cold storage with experiment design and stored for eight-month. In the refrigerator, silica gel was used to maintain relative humidity around $50-55 \%$. Before storage, laboratory tests were carried out and recorded the initial quality of seeds. The samples were drawn and analyzed the seed quality every two-month interval.

\subsection{Data Collection}

\subsubsection{Seed Moisture Content (\%)}

The moisture content of seed samples was determined using the oven method at $105^{\circ} \mathrm{C} \pm 3^{\circ} \mathrm{C}$ for 24 hours with three replications of 100 seeds per treatment (ISTA, 1999). The Petri dishes were dried in oven at $100^{\circ} \mathrm{C} \pm 3^{\circ} \mathrm{C}$ for 1 hour, and cooled in a desiccator for about 30 minutes and weighed (W1). Then the Petri dishes with 1000 seeds were weight before drying (W2) and dried in the oven. The Petri dishes with dried samples were transferred into a desiccator and cooled for 30 minutes and weighed (W3). The seed moisture contents were determined by dry weight basis and were calculated by the following formula:

$$
\begin{aligned}
& \text { Moisture content } \%=\{(\mathrm{W} 2-\mathrm{W} 3) /(\mathrm{W} 2-\mathrm{W} 1)\} \times 100 \\
& \text { Where, } \\
& \mathrm{W} 1=\text { weight of Petri dish }(\mathrm{g}) \\
& \mathrm{W} 2=\text { weight of Petri dish plus fresh seeds }(\mathrm{g}) \\
& \text { W3 = weight of petri dish plus dried seeds }(\mathrm{g})
\end{aligned}
$$

\subsubsection{Germination Percentage}

The germination test was performed using the top paper method. Four replications of one hundred seeds were used per treatment which were randomly distributed on the wet filter paper in Petri dishes $9 \mathrm{~cm}$ in diameter and placed into an incubator set to a constant temperature of $25^{\circ} \mathrm{C}$ throughout the testing period. The germinated seeds ( $2 \mathrm{~mm}$ radicle elongation) were counted daily up to the tenth day to calculate the germination rate (ISTA, 2004).

Germination $(\%)=\frac{\text { Number of seeds germinated }}{\text { Number of seeds tested }} \times 100$




\section{Macrothink}

\subsubsection{Germination Index}

The germination index was computed by using the following formula:

$$
\text { G.I. }=\frac{N_{1}}{D_{1}}+\frac{N_{2}}{D_{2}}+\cdots+\frac{N_{n}}{D_{n}}
$$

Where,

$\mathrm{N} 1, \mathrm{~N} 2 \ldots \mathrm{Nn} \quad=$ Number of seedlings on day 1st, 2nd and nth day after sowing

$\mathrm{D} 1, \mathrm{D} 2, \mathrm{Dn}=$ Number of days after sowing

\subsubsection{Seedling Vigor Index}

This was calculated by determining the germination percentage and seedling length of the same seed lot. The seedlings were grown in between rolled towel paper method. Fifty seeds each in four replications were germinated in the moist towel papers in such a way that the micropyles were oriented towards the bottom to avoid root twisting. The rolled towel papers were kept in the incubator maintained at a temperature of $25^{\circ} \mathrm{C}$. After 10 days, towel papers were removed and five normal seedlings were randomly selected, their length was measured and means seedling length was calculated. For dry weight determination, the seedlings were removed and dried in an oven at $100^{\circ} \mathrm{C}$ temperature for 24 hours, then cooled and weighed. Seed vigor index was calculated by multiplying germination percentage and seedling length $(\mathrm{mm})$ or seedling dry weight $(\mathrm{g})$. The seed lot showing the higher seed vigor index was considered to be more vigorous (Adbdul-Baki and Anderson, 1973).

Vigor index -I: Germination $(\%) \times$ total dry weight of seedling $(\mathrm{g})$

Vigor index -II: Germination $(\%) \times$ Seedling length $(\mathrm{mm})$

\subsection{Statistical Analysis}

Collected data were analyzed by the analysis of variance (ANOVA) using Statistix (version 8.0) software. Treatment means were compared by Least Significant Difference (LSD) at 5\% level.

\section{Results and Discussion}

\subsection{Seed Moisture Content}

The difference of seed moisture content between storage environments was not significant $(\operatorname{Pr}=0.2922)$ (Table 1) by indicating 5.485\% in ambient condition and 5.294\% in cold storage. This result may be appeared by less difference of relative humidity between two environments. The relative humidity was controlled at 50-55\% in cold storage. However, Bezerra et al. (2004) found that when evaluating the physiological quality of morning seeds during storage in a natural environment, the moisture content of seed decreased slowly as the storage period progressed, while for those in a cold room, the variation in moisture content was greater. And the mean effect of packaging materials on seed moisture content was not 
also significant $(\operatorname{Pr}=0.8025)$. The moisture content of sesame $(5.434 \%)$ in woven polypropylene, $(5.305 \%)$ in super bag and $(5.429 \%)$ in metal bin were statistically same. The type of packaging materials cannot influence on the moisture content of sesame over storage period (Table 1). Lima et al. (2014) demonstrated that the PET bottles packaging applied to laboratory environment and freezer environment show uniform averages with minor variations for water content because the impermeable packing (plastic bottle) is able to isolate the seed from the influence of the external surroundings (air), not allowing moisture exchange with the environment. However, in current experiment, the moisture content was not significantly different among packaging materials, except numerically higher in woven polypropylene bag, it may be due to the relative humidity of natural condition in laboratory which was not high enough to influence the effect of type of packages. The relative humidity (55-60\%) was recorded in laboratory during the storage period.

The mean effect of storage duration on the moisture content of seed was significantly different $(\operatorname{Pr}<0.0001)$. The moisture content of seed in initial storage showed the highest value $(7.920 \%)$ and it significantly decreased to the lowest value in two-month $(4.075 \%)$, four-month $(3.789 \%)$ and six-month $(4.215 \%)$, then it rose up again to $6.947 \%$ in eight-month. Therefore, sesame seeds maintained lower moisture content for six-month under storage. Contrary to this finding, Lima et al. (2014) reported that in the natural environment and freezer, the sesame seeds packed in the paper showed a high percentage of moisture in the third month of storage, reaching 10.5 and $12.5 \%$ respectively. In the dry cold room, the greatest percentages of moisture were observed in the third month of storage for those sesame seeds packed in multiwall paper and black polyethylene.

The interaction effect was not occurred between storage environments and packaging materials $(\mathrm{Pr}=0.71)$, between storage environments and durations $(\operatorname{Pr}=0.6323)$, between packaging materials and storage durations $(\operatorname{Pr}=0.8773)$. Moreover, the combined effect of storage environments, packaging materials and storage durations on seed moisture content of sesame was not significant $(\operatorname{Pr}=0.4439)$ (Table 1$)$. Therefore, the changes of the seed moisture content during storage did not depend on the effect of storage environments and packaging materials. The initial seed moisture content decreased to lowest level in two-month, four-month and six-month storage in all treatments (Figure 1). This might be due to the moisture sorption isotherm of the seed. The amount of water vapor that can be absorbed by a product depends on its chemical composition, physical-chemical state, and physical structure. Consequently, the isotherm shape is unique to each product type due to differences in capillary, surface, and colligative effects (Bell and Labuza, 2000). The numerically increased value was occurred in four-month storage of woven polypropylene bag under ambient condition, and in six-month storage of metal bin under cold storage. The moisture content of sesame in eight-month storage was significantly higher than that of six-month storage for all treatments (Figure 1). The increase in the water content of seeds kept in waterproof packaging is due to the higher respiratory rate of the seeds stored in that type of packaging, which provides a greater release of water and an increase in the relative humidity inside the packaging. 
Table 1. Mean effect of storage environments, packaging materials and storage durations on the quality of sesame, 2016-17 cropping season

\begin{tabular}{|c|c|c|c|c|c|}
\hline Treatment & $\begin{array}{c}\text { Moisture } \\
\text { content }(\%)\end{array}$ & $\begin{array}{l}\text { Germination } \\
(\%)\end{array}$ & $\begin{array}{l}\text { Germination } \\
\text { index }\end{array}$ & $\begin{array}{c}\text { Seedling } \\
\text { vigor index } \\
\text { I } \\
\end{array}$ & $\begin{array}{c}\text { Seedling } \\
\text { vigor index } \\
\text { II } \\
\end{array}$ \\
\hline \multicolumn{6}{|l|}{ Environment (E) } \\
\hline Ambient & $5.485 \mathrm{a}$ & $40.417 \mathrm{a}$ & $9.658 \mathrm{a}$ & $0.338 \mathrm{a}$ & $289.420 \mathrm{a}$ \\
\hline Cold storage & $5.294 \mathrm{a}$ & $25.611 \mathrm{~b}$ & $6.612 \mathrm{~b}$ & $0.219 \mathrm{~b}$ & $179.210 \mathrm{~b}$ \\
\hline $\mathrm{LSD}_{0.05}$ & 0.360 & 2.997 & 0.830 & 0.027 & 25.320 \\
\hline \multicolumn{6}{|l|}{ Packaging material (P) } \\
\hline Woven polypropylene bag & $5.434 \mathrm{a}$ & $45.058 \mathrm{a}$ & $11.555 \mathrm{a}$ & $0.390 \mathrm{a}$ & $316.600 \mathrm{a}$ \\
\hline Super bag & $5.305 \mathrm{a}$ & $27.450 \mathrm{~b}$ & $6.462 \mathrm{~b}$ & $0.220 \mathrm{~b}$ & $198.450 \mathrm{~b}$ \\
\hline Metal bin & $5.429 \mathrm{a}$ & $26.533 \mathrm{~b}$ & $6.387 \mathrm{~b}$ & $0.225 \mathrm{~b}$ & $187.900 \mathrm{~b}$ \\
\hline $\mathrm{LSD}_{0.05}$ & 0.441 & 3.671 & 1.017 & 0.033 & 31.011 \\
\hline \multicolumn{6}{|l|}{ Storage duration (D) } \\
\hline Initial storage & $7.920 \mathrm{a}$ & $2.000 \mathrm{e}$ & $0.920 \mathrm{~d}$ & $0.033 \mathrm{~d}$ & $19.120 \mathrm{~d}$ \\
\hline 2-month & $4.075 \mathrm{c}$ & $15.333 \mathrm{~d}$ & $4.795 \mathrm{c}$ & $0.144 \mathrm{c}$ & $119.740 \mathrm{c}$ \\
\hline 4-month & $3.789 \mathrm{c}$ & $20.097 \mathrm{c}$ & $5.214 \mathrm{c}$ & $0.163 \mathrm{c}$ & $116.160 \mathrm{c}$ \\
\hline 6-month & $4.215 \mathrm{c}$ & $52.444 \mathrm{~b}$ & $12.425 \mathrm{~b}$ & $0.405 \mathrm{~b}$ & $410.810 \mathrm{~b}$ \\
\hline 8-month & $6.947 \mathrm{~b}$ & $75.194 \mathrm{a}$ & $17.320 \mathrm{a}$ & $0.648 \mathrm{a}$ & $505.760 \mathrm{a}$ \\
\hline $\mathrm{LSD}_{0.05}$ & 0.566 & 4.739 & 1.313 & 0.043 & 40.035 \\
\hline \multicolumn{6}{|l|}{ Pr > F } \\
\hline $\mathrm{E}$ & 0.2922 & $<0.0001$ & $<0.0001$ & $<0.0001$ & $<0.0001$ \\
\hline $\mathrm{P}$ & 0.8025 & $<0.0001$ & $<0.0001$ & $<0.0001$ & $<0.0001$ \\
\hline $\mathrm{D}$ & $<0.0001$ & $<0.0001$ & $<0.0001$ & $<0.0001$ & $<0.0001$ \\
\hline $\mathrm{E} \times \mathrm{P}$ & 0.7100 & 0.573 & 0.6828 & 0.2564 & 0.2646 \\
\hline$E \times D$ & 0.6323 & $<0.0001$ & $<0.0001$ & $<0.0001$ & $<0.0001$ \\
\hline $\mathrm{P} \times \mathrm{D}$ & 0.8773 & $<0.0001$ & 0.0001 & 0.0001 & 0.0005 \\
\hline $\mathrm{E} \times \mathrm{P} \times \mathrm{D}$ & 0.4439 & 0.2168 & 0.742 & 0.0133 & 0.7053 \\
\hline CV (\%) & 15.84 & 21.51 & 24.18 & 23.19 & 25.61 \\
\hline
\end{tabular}

In each column, means having a common letter are not significantly different at $5 \%$ LSD.

$$
\operatorname{LSD}_{0.05}=1.396
$$

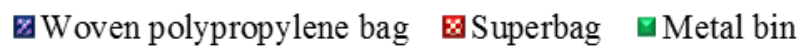

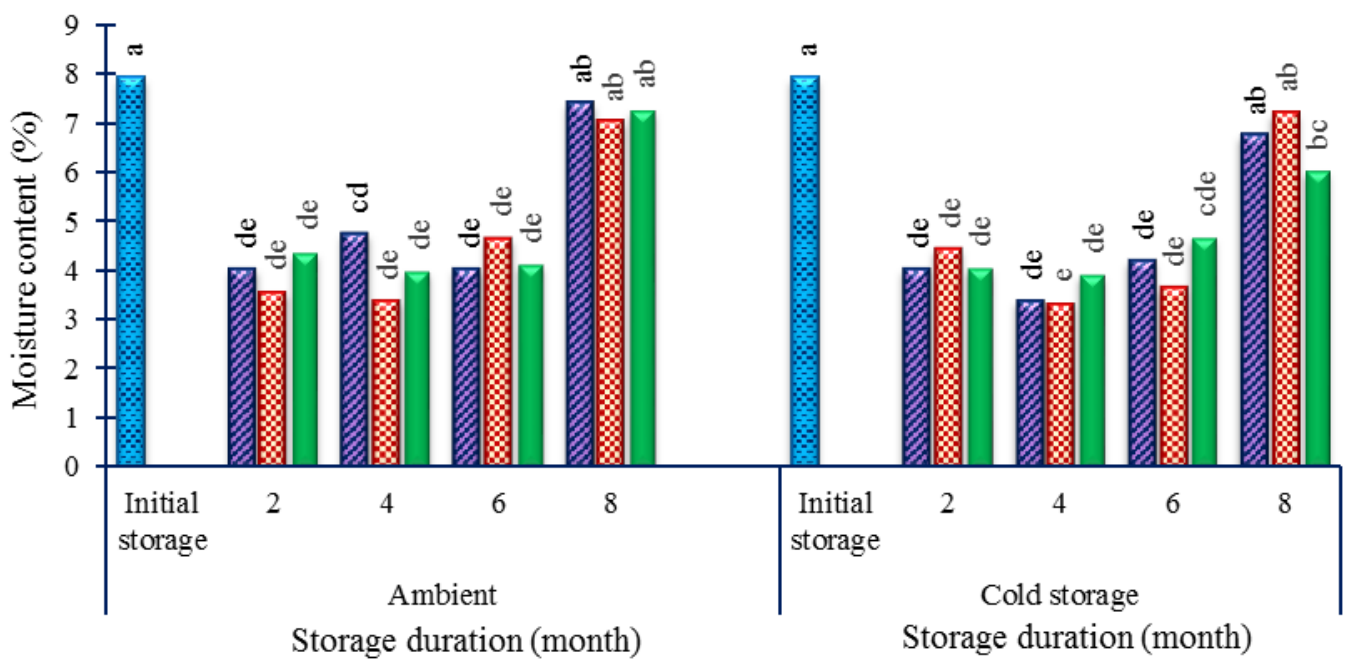

Figure 1. Combination effect of storage environments, packaging materials and storage durations on moisture content of sesame, 2016-17 cropping season 


\subsection{Germination Percentage}

The effect of storage environments (ambient condition and cold storage) on germination of sesame seeds was significantly different $(\operatorname{Pr}<0.0001)$ showing the value $40.417 \%$ in ambient storage followed by $25.611 \%$ in cold storage (Table 1). Lima et al. (2014) investigated the physiological quality of sesame seeds cv. BRS Seda of cream integument found that the seeds remain viable for of up to twelve-month, when stored in a cold and dry room environment and the refrigerator, regardless the type of packaging used, while in the natural environment, the seeds remain viable for up to six-month of storage. However, Mutinda et al. (2017) reported that seeds stored at room temperature had a 5.3\% higher germination than those in cold storage. Increasing storage temperatures alleviated seed dormancy at seed moisture contents between $2.5 \%$ and $12 \%$ in sunflower (Helianthus annuus) (Bazin et al., 2011). In red rice (Oryza sativa L.), storage at $-15{ }^{\circ} \mathrm{C}$ with seed moisture contents of $11 \%$ to $12 \%$ maintained dormancy for up to 1 year (Cohn and Hughes, 1981).

The differences of germination percentage of seeds were occurred among packaging materials, and the maximum germination $(45.058 \%)$ was found in seeds stored in woven polypropylene bag followed by that of seeds stored in super bag and metal bin with $27.45 \%$ and 26.533\%. The ANOVA showed the significant differences among packaging materials with $\operatorname{Pr}<0.0001$ (Table 1). The packaging materials had a significant effect on seed germination under the two storage environments. During storage, there are changes in seed moisture content and temperature which affects seed germination. Low movement of air in stored seeds lowers their quality due to heat accumulation resulting from respiration (Chattha et al., 2012). Moreover, nitrogen and carbon dioxide delayed the complete removal of dormancy about one month as compared with air, but oxygen had no effect on the prolongation of seed dormancy (Tokumasu, 1970). In the current study, sesame seeds stored in super bag and metal bin were in the hermetic condition where almost no exchange of air and moisture between the packaging materials and the store environment. In this system the oxygen content in the inter-granular atmosphere is dramatically reduced, and the carbon dioxide content increases to a level where aerobic respiration is no long possible (Bala et al., 1990). Alternating temperatures were reported to be one of the most useful means to break seed dormancy in Brassica as well as in many other vegetables (Tokumasu, 1970).

In addition, the effect of storage durations of seeds was also significant on the germination of stored seeds $(\operatorname{Pr}<0.0001)$. The germination of stored seeds increased with storage duration and the maximum germination was observed at the end of storage (eight-month) with $75.194 \%$. The minimum germination, $2 \%$, was occurred in initial storage and rose to $15.333 \%$ in two-month, $20.097 \%$ in four-month and $52.444 \%$ in six-month. Therefore, sesame seeds were required to be stored for achieving high germination (Table 1). Aside from seed dormancy loss, both temperature and seed moisture content can also impact the viability of dry-stored seeds. Storage at low temperatures and low seed moisture content generally maintains seed viability. In contrast, storage at high temperatures and high seed moisture content results in decreased seed viability as a result of accelerated aging (Copeland and McDonald, 2001). A specific range of storage temperature and seed moisture content affects the rate of dormancy loss and viability of tangle head seeds. Storage at $10{ }^{\circ} \mathrm{C}$, regardless of 
seed moisture content, tangle head seeds (Heteropogon contortus L.) maintained dormancy and germination of seeds stored at this temperature generally did not improve with storage over time (one year) (Baldos et al., 2014).

The interaction effect between storage environments and packaging materials on the germination of seeds was not significant by $\operatorname{Pr}=0.573$ in ANOVA, however, the interaction effect between storage environments and storage durations, and packaging materials and storage durations expressed significance $(\operatorname{Pr}<0.0001)$ (Table 1). The combination effect of storage environments, packaging materials and storage durations on the germination of seeds showed non-significant result $(\operatorname{Pr}=0.2168)$. Under ambient storage, germination of the seeds stored in different containers increased with storage durations (Figure 2). Germination of seeds stored in woven polypropylene bag rose significantly in every two-month and reached the highest value $(87.333 \%)$ in six-month after storage then maintained until eight-month with $(86.417 \%)$. However, germination of seeds stored in super bag was not different for four-month and then increased significantly in six-month storage. Seeds stored in super bag obtained highest level of germination $(79.25 \%)$ in eight-month, which was non-significant with woven polypropylene bag. Sesame stored in metal bin significantly increased in two-month and the maximum germination was observed in eight-month with $(74.583 \%)$ which was significantly lower than that of woven polypropylene bag. These results showed that the duration for dormancy loss of stored seeds was different among packaging materials. Maximum dormancy loss was observed in six-month in woven polypropylene bag, while it was found in eight-month in super bag. However, based on percent germination data obtained from metal bin storage, it cannot be interpreted that the fully dormancy loss was appeared in eight-month. Among hermetic packaging types, metal bin had the ability to extend the seed dormancy than super bag.

$\mathrm{LSD}_{0.05}=11.607$

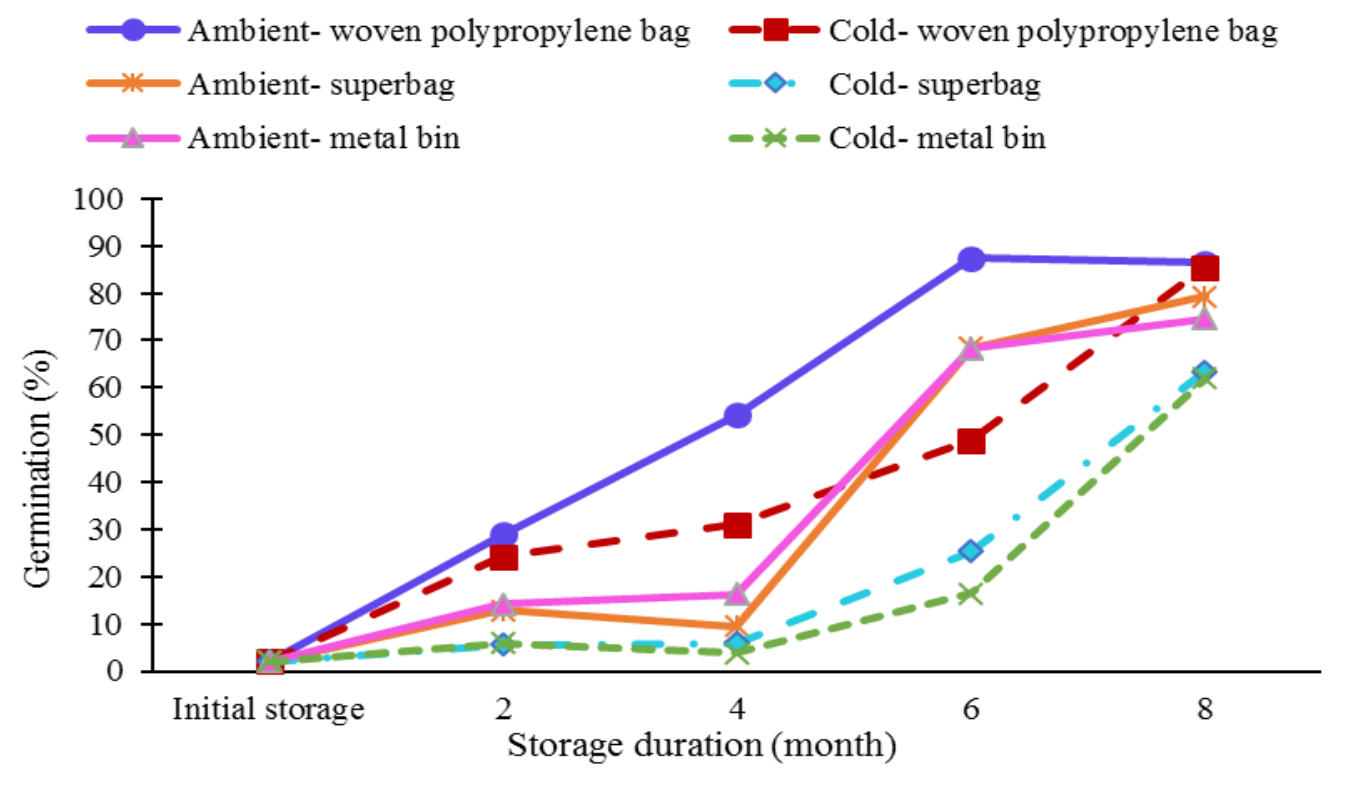

Figure 2. Combination effect of storage environments, packaging materials and storage durations on germination percent of sesame, 2016-17 cropping season 
In cold storage, the highest level of germination (85.5\%) was resulted from woven polypropylene bag in eight-month storage, however, germination of seeds stored in super bag and metal bin were significantly lower in eight-month with $63.5 \%$ and $61.917 \%$ (Figure 2). Moreover, germination of seeds kept in super bag and metal bin did not statistically increase until four-month of storage. Low storage temperatures are known to prevent or delay seed dormancy loss of dry-stored seeds (Bazin et al., 2011). After eight-month storage, seed germination of woven polypropylene bag was different from that of super bag and metal bin in cold storage. Thus, it can be suggested that the seed dormancy loss was observed in eight-month of woven polypropylene bag, however, the dormancy was still maintained until eight-month storage in super bag and metal bin under cold storage. The result of these experiments, therefore, indicated that the storage temperature and packaging materials affected the rate of seed dormancy loss. In all packaging materials, seeds stored in ambient condition showed dormancy release earlier than cold storage, and woven polypropylene bag showed rapid removal of dormancy over other containers. The possibility of these results was being due to the temperature and carbon dioxide effect on dormancy. At low temperatures, inhibition is caused by very small pressures of $\mathrm{CO}_{2}$, while conversely at high temperatures high pressures of $\mathrm{CO}_{2}$ are necessary to maintain continued dormancy. It means a rise in temperature requires an increase amount of $\mathrm{CO}_{2}$ to produce inhibition in the seeds of Brassica alba. Conversely, a fall in temperature reduces the necessary amount of $\mathrm{CO}_{2}$ to cause inhibition (Kidd, 1914). In the current study, although the amount of $\mathrm{CO}_{2}$ in super bag and metal bin was enough to maintain dormancy under cold storage, this amount was not sufficient to extend dormancy under ambient condition.

\subsection{Germination Index}

The mean effect of storage environments on germination index of sesame seeds was significantly different $(\operatorname{Pr}<0.0001)$ (Table 1$)$. Statistically higher germination index (9.658) was obtained under ambient condition followed by (6.61) under cold storage. However, Lima et al. (2014) reported that seeds stored in a natural environment were considered less vigorous than seeds stored in the controlled environments (cold room, refrigerator and freezer) using the first-count germination test. There were significant differences in the average percentage values the FC (first count of germination) and SGT (standard germination test) for Kraft paper packaging between a freezer and laboratory environments through the whole storage period of sesame (Lima et al., 2014).

The ANOVA showed the variation among the packaging materials with the value of $\operatorname{Pr}<0.0001$. Among the packaging materials, seed germination index of woven polypropylene bag showed the maximum value (11.555) which differed significantly from germination index of super bag (6.462) and metal bin (6.387), which were not different between each other. Sarah (2015) reported that there were significant differences between the storage materials for the speed of germination (germination index) of the seeds. The maximum germination index of rice was found in air-tight tin bin followed by woven plastic bag and bamboo basket (Naing, 2017). The use of impermeable packaging prevents the increase in moisture content and rate of deterioration, offering vigorous seeds for a longer period of time (Cunha et al., 2015). 


\section{Macrothink}

The mean differences among storage durations on germination index of sesame seeds was significant $(\operatorname{Pr}<0.0001)$. The germination index of seeds increased with storage period, starting from 0.92 in initial storage to 4.795 in two-month, 5.214 in four-month, 12.425 in six-month and 17.32 in eight-month storage (Table 1). Naing (2017) reported the similar result in rice storage that germination index increased with storage durations, and the lowest germination index was found from no storage while the maximum germination index was seen in four-month and two-month storage.

The interaction effect between storage environments and types of containers was not significant $(\operatorname{Pr}=0.6828)$, however, the significant interaction was occurred between storage environments and durations $(\operatorname{Pr}<0.0001)$, and between packaging materials and storage durations $(\mathrm{Pr}=0.0001)$ (Table 1). The interaction effect of storage environments, packaging materials and storage durations was not significant $(\operatorname{Pr}=0.742)$. Germination index of seeds in woven polypropylene bag achieved statistically higher value than other containers during storage under both storage environments (Figure 3). Moreover, that container gave the maximum value in six and eight-month storage under ambient condition and in eight-month storage under cold storage. Although super bag and metal bin showed the higher value in eight-month, it was significantly lower when compared with woven polypropylene bag. Therefore, storing sesame seeds in woven polypropylene bag was suitable to attain high germination rate under ambient and cold storage for eight-month. It was observed that the germination rate was better in seeds of woven polypropylene bag under both storage environments. The variation in seed vigor may also be due to variations in temperature, moisture content, relative humidity and pathogen activity in the different packaging materials (Raikar et al., 2011). 


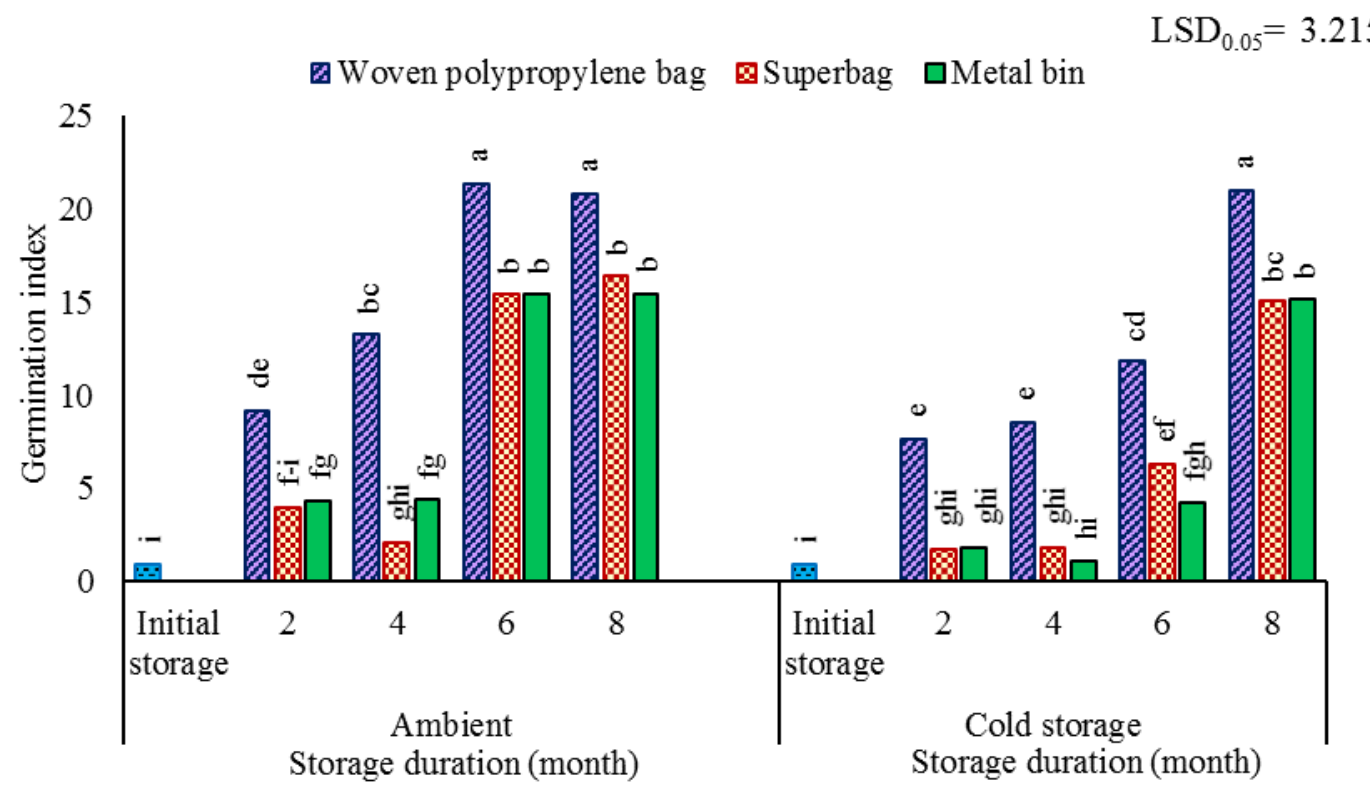

Figure 3. Combination effect of storage environments, packing materials and storage durations on germination index of sesame, 2016-17 cropping season

\subsection{Seedling Vigor Index I}

The mean effect of storage environments on the seedling vigor index I was significant $(\operatorname{Pr}<0.0001)$ (Table 1). The seedling vigor index I of seeds in ambient condition showed the higher value 0.338 and cold storage seeds had 0.219 . When the effect of storage temperature on seed ageing was examined at constant water content, the rate of seed germination loss and vigor decline are shown as storage temperature increased (Murthy et al., 2002).

There was a significant difference among the effect of packaging materials on seedling vigor index I $(\operatorname{Pr}<0.0001)$. Among three types of containers, woven polypropylene bag resulted the highest value of seedling vigor index I (0.39) and it was statistically different with that of super bag (0.22) and metal bin (0.225). Rice seeds stored in polythene and cheese cloth exhibited higher germination, seedling dry weight and length as compared to the other packaging materials tested (gunny, khaki, poly sack) (Mutinda et al., 2017). Similar findings are reported by Raikar et al. (2011) that rice seeds stored in polythene had higher germination percentage, seedling length, seedling vigour index and dry weight.

Regarding storage durations, seedling vigor index I increased with storage duration, by observing 0.033 in initial storage, 0.144 in two-month, 0.163 in four-month, 0.405 in six-month and 0.648 in eight-month, which was the maximum value. The seedling vigor index I of two-month and four-month storage were similar, and the results of ANOVA showed the significant different among storage durations ( $\operatorname{Pr}<0.0001)$ (Table 1). The seedling vigor indexes were significantly higher in all storage duration than the seedling vigor index of rice in no storage (Naing, 2017). 


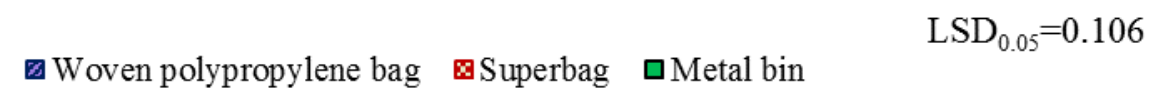

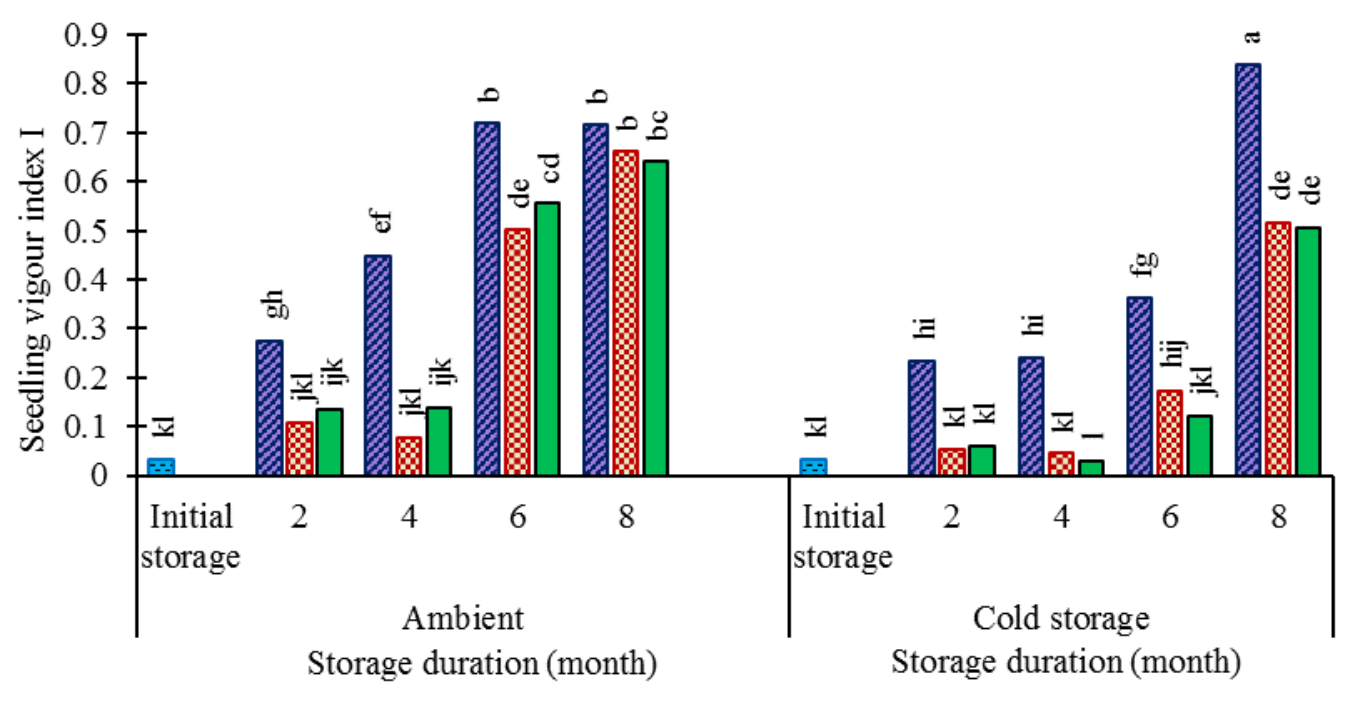

Figure 4. Combination effect of storage environments, packaging materials and storage durations on seedling vigour index I of sesame, 2016-17 cropping season

There was no interaction effect between storage environments and packaging materials in seedling vigor index I ( $\mathrm{Pr}=0.2564)$ (Table 1). However, the interaction effect was occurred between storage environments and storage durations $(\operatorname{Pr}<0.0001)$. Moreover, the interaction effect between storage containers and durations was also significant on the seedling vigor index I ( $\mathrm{Pr}=0.0001)$, and the combination effect of storage environments, packaging materials and storage durations was significant $(\operatorname{Pr}=0.0133)$. The seedling vigor index I increased in storage durations in all storage containers and environments. Seeds of eight-month storage gave the highest values in each container under both storage environments. Under ambient condition, the seedling vigor index I of sesame stored in woven polypropylene bag significantly increased with storage duration. However, seeds stored in super bag and metal bin gave the same value of seedling vigor index I until four-month. Then it increased in six-month and eight-month. The seedling vigor index I of seeds in woven polypropylene was significantly higher than that of other containers in all storage durations except in eight-month (Figure 4). Rosario et al. (2017) reported that seedling vigor index of paddy was significantly different in the different storage materials on the fourth month of storage. Under cold storage, although seedling vigor index I of seeds stored in woven polypropylene bag increased with storage duration and attained highest value in eight-month, super bag maintained the seedling vigor index I until four-month, whereas metal bin showed the stable value until six-month after storage. Woven polypropylene bag resulted higher seedling vigor index I than super bag and metal bin in all storage durations. The highest seedling vigor index I of sesame seeds was resulted from seeds stored in woven polypropylene bag for eight-month under cold storage although rapidly increase of seedling vigor index I was occurred in the same packaging material under ambient condition (Figure 4). Seeds lose their viability and vigor very fast under ambient conditions as the changes in environmental 
conditions like temperature and humidity (Roberts, 1972). Inappropriate seed packaging and seed dormancy affects seed quality and consequently leads to reduced crop stand, low seedling vigor and reduced yields (Mutinda et al., 2017).

\subsection{Seedling Vigor Index II}

The mean effect of storage environments on seedling vigor index II was significantly different $(\operatorname{Pr}<0.0001)$ (Table 1). The statistically higher seedling vigor index II (289.42) occurred in ambient condition followed by (179.21) of seedling vigor index II in cold storage. Heydecker (1969) reported that poor storage conditions greatly affect seed vigor.

The variation of the effect of packaging materials on seedling vigor index II ( $\operatorname{Pr}<0.0001)$ was presented in Table 1. Among storage containers, woven polypropylene bag showed highest seedling vigor index II with the value 316.60 followed by super bag with 198.45 and metal bin with 187.90. Seed viability and vigor significantly depends on the type of storage container (Ali, 1963).

Regarding storage durations, ANOVA results showed the significantly differences among storage durations $(\operatorname{Pr}<0.0001)$. The seedling vigor index II was the lowest in initial storage (19.12), and increased with storage durations. The value of seedling vigor index II in two-month (119.74) and four-month (116.16) were in the same level, then statistically rise up in six-month (410.81) and reached the highest value (505.76) in eight-month. However, Copeland (1976) reported that seedling vigor declines rapidly with the length of seed storage.

There were interaction effects between storage environments and storage durations $(\operatorname{Pr}<0.0001)$, and between packaging materials and durations ( $\operatorname{Pr}=0.0005)$. However, the interaction effects between storage environments and packaging materials ( $\operatorname{Pr}=0.2646)$ was not found. Moreover, the combination effect of storage environments, packaging materials and storage durations ( $\mathrm{Pr}=0.7053)$ was also not significant (Table 1). Under ambient condition, the highest seedlings vigor index II was found in seeds stored in woven polypropylene bag for six-month. Then, it decreased significantly in eight-month, however, seedling vigor index II of six-month and eight-month storage were similar in super bag and metal bin. Furthermore, seedling vigor index II did not significantly increase until four-month after storage in these two types of containers. The same result was also found in super bag and metal bin under cold storage. After eight-month, seedling vigor index II was similar in all storage condition except in metal bin under cold storage, which was significantly lower than other types of containers. The highest seedling vigor index II resulted from woven polypropylene bag in six-month storage under the ambient condition (Figure 4). The value of seedling vigor II depends on the germination and seedling length. In the present study, seed germination significantly increased with the storage period increased due to the dormancy effect, therefore, seedling vigor II also increased during storage. 


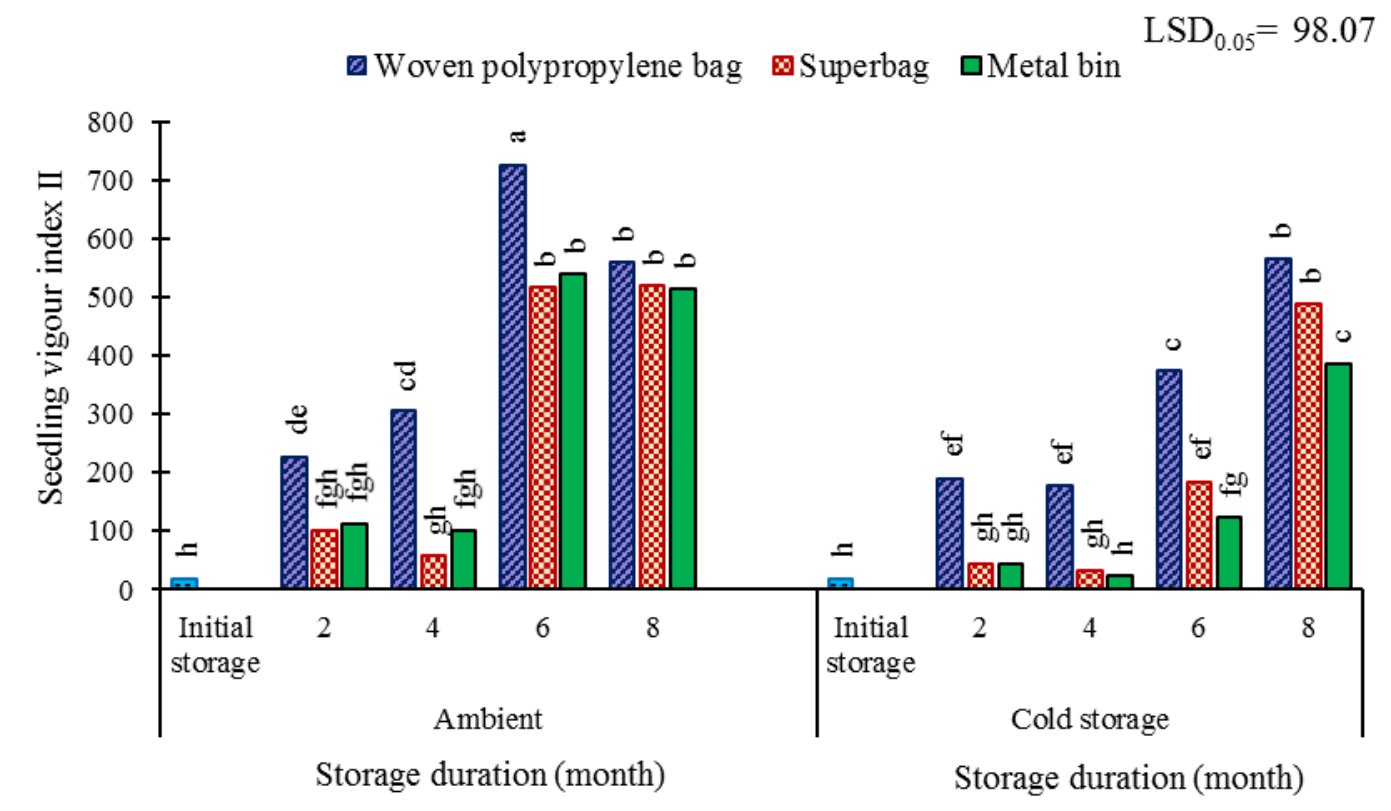

Figure 5. Combination effect of storage environments, packing materials and storage durations on seedling vigour index II of sesame, 2016-17 cropping season

\section{Conclusion}

The black sesame was tested in a woven polypropylene bag, IRRI super bag and a metal bin under ambient and dry cold conditions for eight-month. During storage, seed moisture content was influenced by storage duration, but not by packaging types and storage environments. All packaging materials showed the same trend for moisture content by sustaining until six-month then increasing in eight-month storage. It can be suggested that all packaging materials can maintain moisture content only for six months. Thus, the re-drying and packaging of sesame may be required for more than six-month storage to avoid increasing moisture content. Germination increased with the advancement of storage durations, and germination index, seedling vigor index I and II were observed in the same trend of germination percent. The fully dormancy release of seeds under ambient condition was earlier than cold storage. The germination per cent of seed under cold storage has not reached highest level until eight-month of storage. Therefore, cold storage is not necessary for eight-month storage of black sesame seed. Among packaging materials, woven polypropylene bag showed the early dormancy break than other airtight containers, super bag and metal bin, under both storage environments. The effect of $\mathrm{CO}_{2}$ influenced on the dormancy release of sesame. So, to achieve fully dormancy release early, farmers and seed companies should keep the seeds under the non-airtight condition with storage pest control measure.

\section{Acknowledgement}

The present research was financially supported by YAU-JICA Technical Cooperation Project. 


\section{References}

Abdul-Baki, A. A., \& Anderson, J. D. (1973). Vigor determination in soybean seed by multiple criteria. Crop Sci., 13, 630-633.

https://doi.org/10.2135/cropsci1973.0011183X001300060013x

Ali, M. K. (1963). Effect of storage containers on the moisture level, viability and other qualities of jute seed. Pak. J. Sci. Res., 15, 3-5.

Bala, B. K., Satter, M. A., \& Alam, M. S. (1990). System dynamics simulation of food grain procurement, Release and Import System in Bangladesh.

Baldos, O. C., Frank, de, J., Kramer, M., \& Sakamoto, G. S. (2014). Storage humidity and temperature affect dormancy loss and viability of tangle head (Heteropogon contortus) seeds. Hortscience, 49(10), 1328-1334. https://doi.org/10.21273/HORTSCI.49.10.1328

Bazin, J., Batlla, D., Dussert, S., El-Maarouf-Bouteau, H., \& Bailly, C. (2011). Role of relative humidity, temperature, and water status in dormancy alleviation of sunflower seeds during dry after-ripening. J. Expt. Bot., 62, 627-640. https://doi.org/10.1093/jxb/erq314

Bell, L. N., \& Labuza, T. P. (2000). Moisture sorption: practical aspects of isotherm measurement and use. American Association of Cereal Chemists, St. Paul, MN.

Bezerra, A. M. E., Filho, S. M., Freitas, J. B. S., \& Teófilo, E. M. (2004). Avaliação da qualidade das sementes de Moringa oleifera Lam. Durante o armazenamento (Evaluation of quality of the drumstick seeds during the storage). Ciência e Agrotecnologia, 28(6), 1240-1246. https://doi.org/10.1590/S1413-70542004000600004

Brooker, D. B., Arkema, F. W. B., \& Hall, C. W. (1992). Drying and storage of grains and oilseeds. New York, Van Nostrand Reinhold.

Chattha, S. H., Jamali, L. A., Ibupoto, K. A., \& Mangio, H. R. (2012). Effect of different packing materials and storage conditions on the viability of wheat seed (TD-1 variety). Science, Technology and Development, 31(1), 10-18.

Cohn, M. A., \& Hughes, J. A. (1981). Seed dormancy in red rice (Oryza sativa) I. Effect of temperature on dry-after ripening. Weed Sci., 29, 402-404.

https://doi.org/10.1017/S0043174500039898

Copeland, L. O. (1976). Principles of seed science and technology. Burgess Pub. Com., Minnaeapolis, Minnesota, pp.164-165.

Copeland, L. O., \& McDonald, M. B. (2001). Principles of seed science and technology. Seed Sci. Res., 20, 1-12. https://doi.org/10.1007/978-1-4615-1619-4

Cunha, D. A., Lisboa, C. F., Teixeira, I. R., Campos, A. J., \& Devilla, I. A. (2015). Physiological potential of the black sesame (Sesamum indicum) seeds in reply to the storage conditions. Australian Journal of Crop Science, 9(7), 671-677.

Hendry, G. A. F. (1993). Oxygen, free radical processes and seed longevity. Seed Science 
Research, 3, 141-153. https://doi.org/10.1017/S0960258500001720

Heydecker, W. (1969). The vigor of seeds-a review. Proc. Int. Seed Test Assoc., 34, 201-209.

ISTA (International Seed Testing Association). (1999). International Rules for Seed Testing. Seed Science and Technology, 27, 340.

ISTA (International Seed Testing Association). (2004). International rules for seed testing annexes. International Seed Testing Association (ISTA), Zurich, Switzerland.

Kidd, F. (1914). The controlling influence of carbon dioxide in the maturation, dormancy and germination of seeds. Part II. https://doi.org/10.1098/rspb.1914.0046

Lima, D. C., Dutra, A. S., \& Camilo, J. M. (2014). Physiological quality of sesame seeds during storage. Rev. Ciênc. Agron., 45, 138-145.

https://doi.org/10.1590/S1806-66902014000100017

Murthy, U. M. N., Kumar, P. P., \& Sun, W. Q. (2002). Mechanisms of seed ageing under different storage conditions for Vigna radiata (L.) Wilczek: lipid peroxidation, sugar hydrolysis, Maillard reactions and their relationship to glass state transition. Journal of Experimental Botany, 54(384), 1057-1067. https://doi.org/10.1093/jxb/erg092

Mutinda, Y. A., Muthomi, J. W., Kimani, J. M., Cheminigw'wa, G. N., \& Olubayo, F. M. (2017). Viability and dormancy of rice seeds after storage and pre-treatment with dry heat and chemical agents. J. Agric. Sci., 9(7). https://doi.org/10.5539/jas.v9n7p175

Naing, A. A. (2017). Grain and seed quality of Manawthukha rice (Oryza sativa L.) as affected by different storage containers and storage durations. Master Thesis, Yezin Agricultural University.

Oyekale, K. O., Nwangburuka, C. C., Denton, O. A., Daramola, D. S., Adeyeye, J. A., \& Akinkuotu, A. O. (2012). Comparative effects of organic and inorganic seed treatments on the viability and vigour of sesame seeds in storage. Journal of Agricultural Science, 4(9),

187-195. https://doi.org/10.5539/jas.v4n9p187

Raikar, S. D., Vyakarnahal, B. S., Biradar, D. P., Deshpande, V. K., \& Janagoudar, B. S. (2011). Effect of seed source, containers and seed treatment with chemical and biopesticide on storability of scented rice. Karnataka Journal of Agricultural Science, 24(4), 448-454.

Roberto, L., Benech-Arnold \& Rodolfo A. Sánchez (ed.). (2004). Handbook of Seed Physiology. Applications to Agriculture. Food Products Press and The Haworth Reference Press, imprints of The Haworth Press, Inc., 10 Alice Street, Binghamton, NY.

Roberts, E. H. (1972). Storage environment and the control of viability cytological, genetical and metabolic changes associated with loss of viability. In: Roberts, E. H. (ed.) Viability of seeds. Chapman and Hall, London, UK, pp. 14-58.

https://doi.org/10.1007/978-94-009-5685-8_2

Rosario, del M. R., Lucero, C. R., Sollestre, R. L., \& Villaluz, R. J. G. (2017). Development and evaluation of a charcoal-insulated paddy storage bin. American Journal of Engineering 
Research, 6(1), 128-133.

Sarah, A. N. (2015). Effects of storage material on the seed quality characteristics of four rice varieties in Ghana. Department of Horticulture, Faculty of Agriculture, College of Agriculture and Natural Resources, Kwame Nkrumah University of Science and Technology, Kumasi. $75 \mathrm{p}$.

Tokumasu, S. (1970). Effect of dry and wet storage upon seed dormancy in cruciferous vegetables. Jour. Japan. Soc. Hort. Sci., 40(1). https://doi.org/10.2503/jjshs.40.23

Tung, L. D. \& Serrano, E. P. (2011). Effects of warm water in breaking dormancy of rice seed. Omonrice, 18, 129-136.

Wu, T., Yang, C., Ding, B., Feng, Z., Wang, Q., He, J., \& Wan, J. (2016). Microarray-based gene expression analysis of strong seed dormancy in rice cv. N 22 and less dormant mutant derivatives. Plant Physiology and Biochemistry, 99, 27-38.

https://doi.org/10.1016/j.plaphy.2015.12.001

\section{Copyright Disclaimer}

Copyright for this article is retained by the author(s), with first publication rights granted to the journal.

This is an open-access article distributed under the terms and conditions of the Creative Commons Attribution license (http://creativecommons.org/licenses/by/3.0/). 